\title{
Meaning of the Initial Teacher Training Path: A Perspective by Gender
}

\section{Fabiola Talavera-Mendoza ${ }^{a}$, Fabian Rucano-Paucar ${ }^{b}$, Héctor Exequiel Gamero Torres ${ }^{c}$, Fernando Pari-Tito ${ }^{\text {, }}$ Klinge Villalba-Condori ${ }^{\mathrm{e}}$}

${ }^{a}$ Universidad Nacional de San Agustín de Arequipa, Perú. E-mail: ftalaveram@unsa.edu.pe

bUniversidad Nacional de San Agustín de Arequipa, Perú. E-mail: frucano@unsa.edu.pe

'Universidad Nacional de San Agustín de Arequipa, Perú. E-mail: hgamerot@ unsa.edu.pe

${ }^{d}$ Universidad Nacional de San Agustín de Arequipa, Perú. E-mail: fpari@unsa.edu.pe

eUniversidad Católica de Santa María, Perú. E-mail: kvillalba@ucsm.edu.pe

Article History: Received: 11 January 2021; Accepted: 27 February 2021; Published online: 5 April 2021

\begin{abstract}
The article aims to report the pedagogical journey of the essence of the reflection of the theory and practice of initial training students, by gender, based on the development of the training plan and educational experiences in pre-professional practices. The objective is to analyze the effectiveness, impact and transfer of the university training process in pedagogical practice. The methodology used was qualitative, based on the beliefs of the students to arrive at subjective theories. An interview and the focus group technique were used. The analysis took place around career choice, teacher orientation, satisfaction, teacher performance, change of conceptions, finding ten common categories. We end by extrapolating the need for accompaniment, the relationship between theory and practice; the preference and greater opportunities for the female gender; These findings make it possible to contribute to the resignification of pedagogical conceptions, approaches and practice models.
\end{abstract}

Keywords: Initial Training, Teaching Practice, Teaching and Training.

\section{Introduction}

The concept of pedagogical practices is becoming more and more relevant as a result of the accreditation process. Curricular reforms undertaken by many universities, converging into collaborative actions that allow teachers, accompanying persons, tutors, principals and practitioners to implement actions to solve problems (Tobón, Martínez, Valdez and Quiriz, 2018), which involve the use of strategies and instruments that allow accompanying persons to carry out processes of feedback and meta-cognition to strengthen classroom practise (Zambrano, 2018).

In the training process in higher education, there is research that tries to explain the integration of theory and practice from a reflective, systematic, critical and situated position; that allows for quality learning, contrasting experiences at the emotional, disciplinary and pedagogical levels (González, Eguren \& Belaunde, 2017), as well as understanding the tensions of professional identity suffered by beginning teachers who preferred problemcentred rather than emotion-centred coping strategies, showing that women presented greater tension than men (Pillen, Beijjard \& Brok, 2013). However, Alvarez (2012) emphasised the correspondence between saying, thinking and doing, but this triangulation is limited by the tensions that can lead to feelings of powerlessness and anger (Pillen et al., 2013; Deng et al., 2018).

In this sense, in the configuration of the curricular itineraries, we found that there are two curricular plans in the Faculty of Education 2009 and 2017 (Universidad Nacional de San Agustín [UNSA], 2016), in the case of the first one is considered the discontinuous practices (fourth year) 8 hours practices with (6 credits) and in the continuous practices 50 hours with (30 credits) in the fifth year, which we will analyse, in-depth, trying to understand the needs, challenges and requirements of the students of initial formation close to graduation, centred in a curricular model by objectives. In contrast, the second curricular plan would be evaluated in 2021 and is centred on a skills approach, but following the same methodology about the accompaniment or tutoring of the student intern. Therefore, it is necessary to emphasise the binomial university and school where the practices of initial formation become an authentic and valuable space (Jones et al., 2016), is that the following study problem arises How do training trajectories allow categorising the effectiveness, impact and transference of training or curricular development in pedagogical practice? What new meanings of initial formation that potentials or make difficult the concretion of theory and practice in training services? How do students of initial formation perceive the gender approach?

There are no studies that show the strengths and weaknesses of students' trajectories in pedagogical practices and their relationship with the training curricula of the faculties of education in Peru. A study on the effects of 
initial training is necessary to guide the service of continuing education (Gilbert \& Gibbs, 1999), and there is a latent gap that the National Education Project. Therefore, it is important to reflect and argue critically on the theoretical-practical bases and categories that emerge from the conception, effectiveness, impact, and transference of pre-professional practices to meet the challenges and transformation of future teachers to optimise their personal and professional development (Villalba-Condori, Adúriz-Bravo, Lavonen, Wong, Wang, 2020).

Initial training is responsible for students' professional preparation for school teaching, inserting them into the pedagogical field through specific programs that qualify and certify their status as teachers before society (Sánchez, 2013). Therefore, initial training constitutes the beginning of the professional training path; through this, the future teacher receives the theoretical-methodological tools to develop their practice in a specific pedagogical field, through formal educational programs (Salazar-Gomez and Tobón, 2018; Ezquerra, Juanas and Martin, 2015). Likewise, university teachers are often criticised for leaving their students on their own, where accompaniment actions are not reflected in reflective and situated actions that allow for a change in practice (Loughran, 2014; Deng et al., 2018). The experiences of Singapore, the United States, Australia, Canada, Finland, among others, propose programmes to connect theory and practice through the design of courses that lead to the development of critical and reflective thinking, creating new models for teaching called "training schools", focusing on learning and assessment (Quatrocchi et al., 2017) (Quispe-Bendezú et al., 2020).

Initial teacher training is provided through the institutional curriculum, requiring moving through subjects, courses and modules, a starting point for analysing training plans and programmes (Villalba-Condori, AdúrizBravo, García-Peñalvo, and Lavonen, 2019). Likewise, students in initial training in the experience of this research, perform pre-professional practices from the seventh semester in educational institutions that allow a gradual immersion in the educational or school reality, under the guidance of the teaching monitors of the Faculty and classroom tutors belonging to a school institution, as we can see in Figure 1.

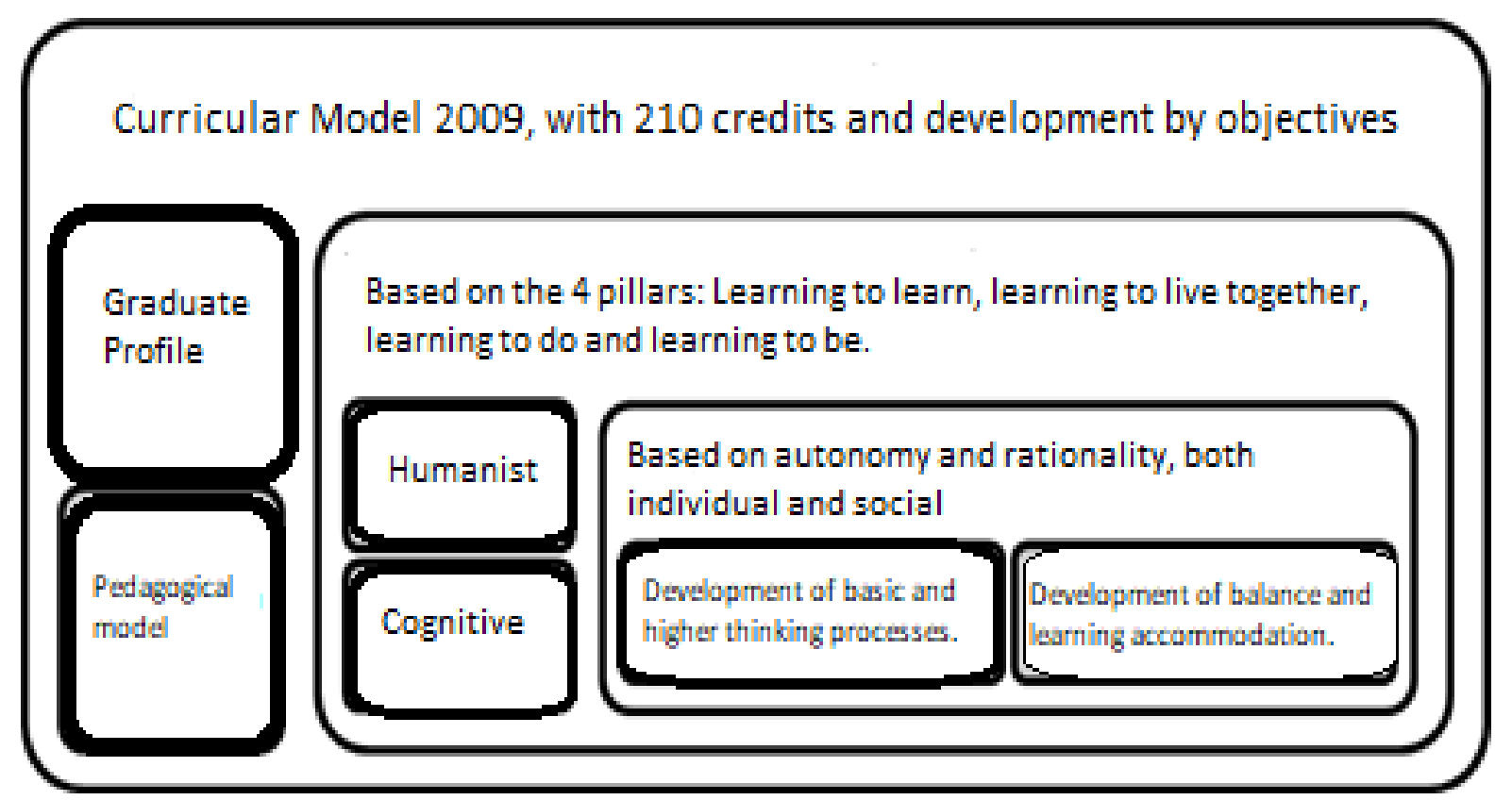

Figure 1. Curricular model 2009

Source: Curricular restructuring in 2009.

Progressive practice as a curricular activity included in students' training process in education plays an important role. To achieve this analysis, one must start from the practical experiences of students in training and the inherent principles such as (1) Promoting situated and contextualised learning, (2) Articulating theory and practice through reflection, (3) Fostering a gradual insertion into the school system, (4) Fostering an accompanied insertion and (5) promoting a collaborative link between the school system and the university (Gorichon, Ruffinelli and Cisternas, 2015). The 2017 curriculum model is aligned with this study, theoretically speaking, but the accompaniment and follow-up practices remain the same as in 2009. 
Table 1. Training plan for continuous and discontinuous pre-professional practices (2009-2017)

\section{DISCONTINUED PRE-PROFESSIONAL PRACTICES I - II}

2017

Aimed mainly at the observation, collection and systematisation of pedagogical,

administrative and institutional information.

CONT

IINUOUS PRE-PROFESSIONAL PRAC the preparation of official documents at the

$\simeq$ beginning, process and end of the academic

year, respecting the school's rules, the internal

directives of the school, fully adapted to the

$\sum_{\text {I }}$ pedagogical, administrative and institutional

management of each school.

Source: Study Plan 2009-2017

We understand that thinking about "pedagogical practices", leads to respond to the needs of training and professional improvement (Salazar-Gomez and Tobón, 2018), which implies, on the one hand, the consideration of the sense of the trajectories of exit of the students, of the subjective and objective conditions and on the other hand it supposes the aspects related to the process of construction of the professional identity (Beltrán, Iparraguirre, Castagno, Fornasari and Gutierrez, 2012). Therefore, these units of analysis contemplate the implementation and development of the strategies materialised in the classroom (Forgiony-Santos, 2017), which are internalised through the following types of pedagogical practices (1) motivation and support for the achievement of expected learning, (2) knowledge management and co-creation of knowledge, (3) problem solving and entrepreneurship to improve living conditions; (4) ethical life project, (5) collaborative work and inclusion, (6) assertive communication, (7) creativity and innovation, (8) transversality, (9) resource management, and (10) formative metacognitive evaluation (Tobon et al., 2018).

Thus, university classrooms should not be disconnected from school contexts' practical experiences that should be the precursors of the debate between theory and practice (Zeichner, 2010). Therefore, it is important through the reflective processes to know one's thinking and action in the educational process by gender (AriasChávez, Ramos-Quispe, Villalba-Condori, Postigo-Zumarán, 2020). Teacher training allows the acquisition of formal and informal learning experiences (Martínez, Martínez and Gezuraga, 2013). In this process there are two types of learning needs: (a) Pedagogical practices that regulate school coexistence, moral and emotional development of students, through respect, affection and commitment and (b) Academic, pedagogical practices: consisting of learning procedures on how to teach (Martínez et al., 2013), interacting theory with practice, understanding that we must adopt a globalised curriculum, for individual and interactive, creative and innovative work (Díaz, 2015). Therefore, during his or her training, the future educator should have the opportunity to review his or her own academic experience; question what is accepted as natural in terms of male or female preference and decide not to reproduce stereotypes. Therefore, it is not reproducing stereotypes either in teacher training or in teaching practice (Vargas, 2012). What should be sought is to be authentic in the classroom development, taking into account all the knowledge acquired.

The gender approach makes it possible to analyse the social relations established between men and women in various contexts. In turn, it explains the inequalities between men and women, emphasising the notion of multiple identities (Quatrocchi et al., 2017). In this sense, it is important to relate whether there are differences in the treatment of teachers towards students due to their gender and whether there are any differences, such as those that affect the assignment of tasks and their academic performance. This analysis from a gender perspective makes it possible to identify problems and needs for personal, professional and social development that guide individual and group behaviour that reproduce norms, values and behaviours that are socialised and learned through the family, social and health policies, and educational and employment programmes (Calixto, Abascal and Martínez, 2018). This gendered approach focuses on interaction, dialogue and relationships (Rodríguez, Gracia, Chan and Camargo, 2019). Moreover, professional development itself is conditioned by the social meanings regarding gender that characterise a culture (Gilbert \& Gibbs, 1999; Kreber, Brook, \& Policy, 2001; Stes, Min-Leviveld, Gijbels \& Van Petegem, 2010). 
Table 2. Evaluation models for university teacher training

\begin{tabular}{lll}
\hline Authors & Levels & \\
\hline & $\bullet$ & Changes in the development of teacher orientation. \\
Gilbert \& Gibbs (1999) & - & Reasons and meanings of career choice. \\
& $\bullet$ & Reflective practice \\
Kreber, Brook \& Policy (2001) & - & Perceptions of satisfaction with the program. \\
& - & Perceptions of teacher performance. \\
Stes et al. (2010) & - & Carticipants' beliefs and approaches to teaching and learning \\
\hline
\end{tabular}

Source: Adapted from Feixas, Lagos, Fernández y Sabaté (2015)

Faced with these questions, the current educational scenario calls for new behaviours and discipline of the training processes (Díaz, 2015). Hence, the need arises to start from the students' training path's subjectivities to evaluate the impact of this transfer of the training services offered in a Faculty of Education Sciences.

\section{Methodology}

It belongs to a qualitative methodology that starts from the concrete experience in its natural and historical context, attributing meanings to their lived experience. For this reason, the data collection technique is an indepth interview, through a focus group (Herrera, 2017), which allowed for the spontaneous compilation of information on the meanings and hierarchies of beliefs and values of the interviewee.

The population studied were the students of the IX semester of the Faculty of Education Sciences, the sampling is non-probabilistic of intentional type to capture abundant information, and in-depth of each selected case, the analysis of 12 subjects has been assigned, guaranteeing the objective, novel and quality information (Suárez, Moral and González, 2013), for their respective codification of inductive character, for a previous analysis through the atlas ti, 10 categories were evidenced that emerge from the hermeneutic unit. It is very important to give meaning and to understand the action of the students of professional practices, through academic trajectories (Serrano, 2016), the software atlas ti was used, to establish the categories and patterns with causal inferences. Three phases were executed, which are detailed:

First phase: We worked on in-depth interviews, giving meaning to elements such as pedagogical practice, teacher performance, beliefs, roles, attitudes, accompaniment, pedagogical practices, career choice and conceptions.

Second phase: The students' arguments in the group interviews were categorised.

Third phase: Three inter judges were given reliability; the process consisted of reviewing the selected segments (units of analysis) and categories. Later, a reorganisation and discarding of some categories in those points observed as weak was carried out, and the thematic contents (subcategories) were determined.

Table 3. Students' perceptions about evaluation

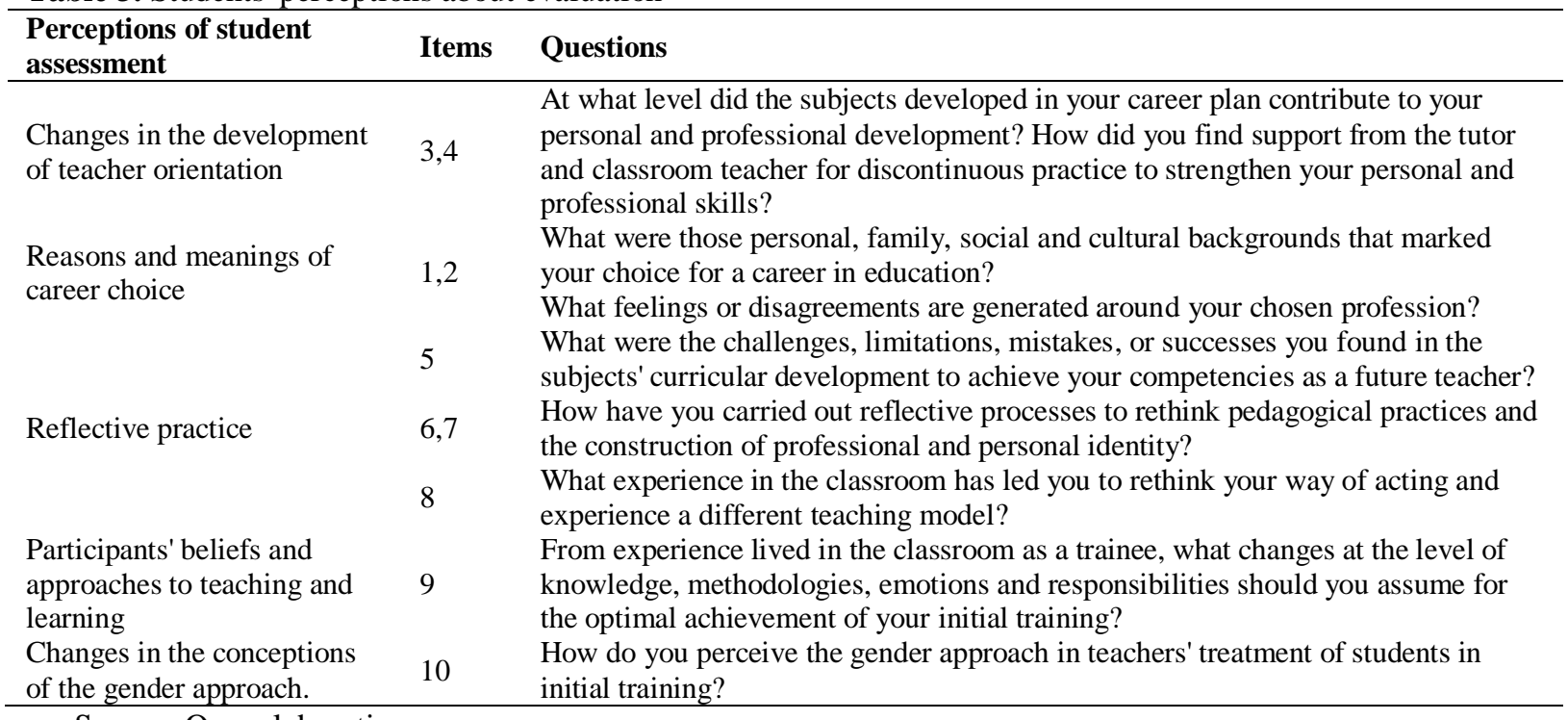

Source: Own elaboration 


\section{Results}

Table 4. Perceptions, categories and subcategories

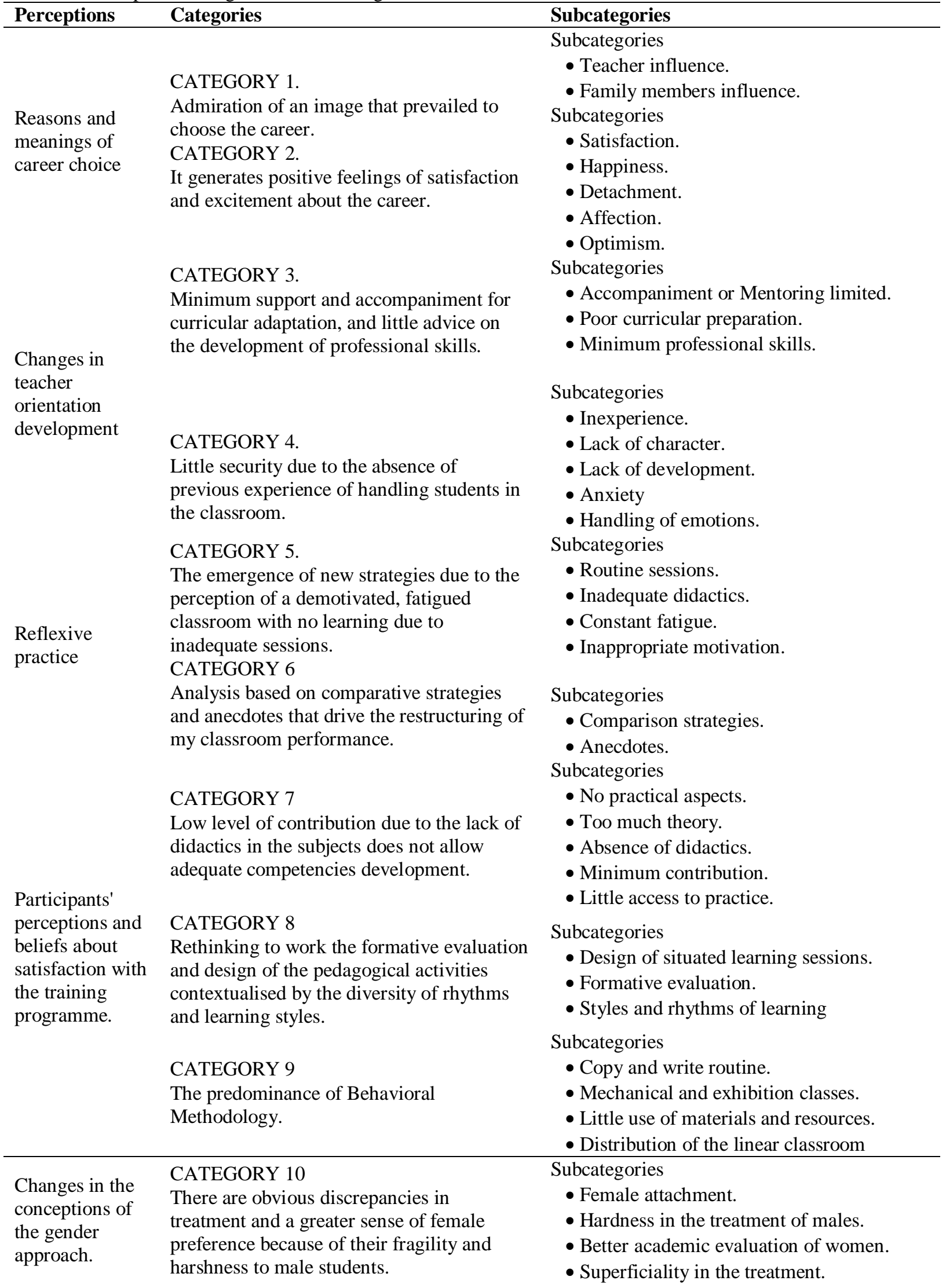

Source: Atlas ti processing, Focus Group to students in initial training. 


\section{Discussion}

\section{Reasons and Senses for the Career Choice}

The study found that most students chose a career because of a teacher's influence at their school, who was the role model, followed by family influence. Coinciding with the study by (Pidello, Rossi and Sagaztizabal, 2013), the teacher's influence on the student prevailed.

Category 1: Admiration of an image that prevailed to choose the career.

- M4. My father was in the military, liked to prepare material to take to the cadets he trained, and I liked to observe the material he prepared. My mother was very dedicated, and her job was to train us ... as my brothers were a little older they were already dedicated to other things, and nobody helped my last sister, and I assumed the role of teacher, I sat with her to teach her. Also, I influenced my history teacher because I chose the speciality of social sciences... there was a little conflict when I decided on a career in education with my father because he thought I was going to be in the military, at the end he gave me his support

- F4. I always liked to teach, and at the same time I was influenced by the teachers who taught me in high school, and this was a great advantage for me, even though my parents thought I would abandon the career, I assumed it with responsibility, and I consider that I was not wrong.

Consequently, feelings of emotion and pleasure about the chosen career are generated in the interviewees, and another category emerges.

Category 2: Generates positive feelings of satisfaction and excitement about the career.

- M6. The shocking moment was when a student came up to me and gave me an apple. I had a unique feeling, the detachment of this student filled my heart, and it taught me that I must redouble my effort to be the best teacher and to be able to reach each one... with the development of the interesting learning sessions ... where the affection of the students is invaluable.

- F2. I feel satisfied to have chosen this profession because I like teaching. During the process, I could feel satisfaction and emotion, for seeing how they learn; this encourages me to keep striving to achieve their attention, creativity and desire to prepare myself even more. The demonstrations of affection... are aspects that fill you, comfort you and encourage you, in the same way, to give back their detachment with love and to prepare me to be better every day.

\section{Changes in the Development of Teacher Orientation}

From the point of view of the development of the pedagogical practices, they were limited by the minimum accompaniment that the teachers-monitors carried out to the students of practices, they did not find support for the development in the classroom environment, Emerging the development of minimum competences in the formative path of the didactic subjects, It is, therefore, essential to create a dynamic and interactive relationship of professional exchange to guide and assist the new or emerging professional (Larenas and Diaz, 2012), but it requires training that meets the requirements of educational policies (Contreras, Font and Gargante, 2018).

Category 3: A minimum of support and accompaniment for curricular adaptation, and little advice on developing professional skills.

- M2. I found many contradictions between what was developed in the subjects and what is worked on in the classroom. The few times my teacher was a monitor, he only sat down to review and ask me what we are working on and did not reach a deep and collective reflection of the learning needs that we have in the performance as a practitioner. However, the grades that I received were very low without knowing my reality and development.

- F3. The accompaniment did not allow for reflection and collegial work, since it was only limited to the filling out instruments to see if we complied with the activities and pertinent documentation. Still, there was no consensus on the learning needs and problems of preparing and managing a learning session.

In this state of vulnerability perceived by the students in initial formation, feelings of fear and insecurity, anxiety, in other cases lack character due to not possessing the necessary skills to be able to perform efficiently were evident, leading to states of frustration and anger with oneself, because of the few opportunities offered to 
them in initial formation to experiment in school environments. The relationship between these points reflects the image that the student information has and the conflicts that he must face in the classroom. When effective accompaniment is not generated, it can generate frustration and restlessness in the students' initial formation (Contreras, Font and Gargante, 2018), which is also supported by our work. Therefore, the emotional dimension is a transversal axis to sustain the work between the classroom teacher, the mentor and the student (Martín, Conde and Mayor, 2014).

Category 4: Poor safety due to lack of previous management experience of the students in the classrooms.

- M4. The first time I was left in a classroom, it was difficult to control it, I never had any experience, and it was something traumatic. After all, the students took advantage of it to not maintain order, ... the director who was a classroom teacher would come out at every moment and leave me in charge of the classroom, ... when problems arose in the class I felt frustrated because I could not regulate my emotions ... the feedback is a key piece.

- F2. At the beginning of my internship I had special students, one with autism and one with hyperactivity, my teacher was older, focused on the other students and left the children aside ... I was frustrated because I didn't know what to do, I was looking for support from teachers and psychologists, .... it generated a lot of anxiety because I wanted them to learn, it was difficult, but, I also needed accompaniment to generate spaces for reflection and shared criticism ... in topics such as: how to organise the activities in the classroom, methodology, management of their emotions, curriculum planning, evaluation and systematisation of the experiences.

\section{Reflexive Practice}

In the studies carried out on the analysis of situations located in the classroom, where there is no room for expository, abstract and routine classes.., the use of the anecdote can become a starting point for an innovative proposal in teacher training sustained in the studies of (Contreras, Font and Gargante, 2018), as well as creating discursive spaces to construct and reconstruct their teaching identities, on their learning trajectory associated with their beliefs, values and pre-professional practices, forming in each semester therapeutic communities to share, discuss and analyse the experiences. In turn, teacher trainers can take the critical parts of these experiences, to incorporate them into their subjects Yazan, B. (2019). In this sense, it is necessary to objectify the experience, using diverse narrative strategies that allow them to reconceptualise their approaches to recover their autonomy in the classroom (Bedacarratx, 2012). Even this aspect is very weak in the curricular proposal's training processes, which can become the motor for promoting reflection and good practices.

Category 5: The emergence of new strategies through the perception of a demotivated, fatigued classroom with no learning due to inadequate sessions.

- M4. In pedagogical practise development, many teachers do not use didactic resources, and the students get tired. In my case, the teacher talks a lot, and the didactic sequence is not aligned to their personal needs and interests. There are constant student fatigue and poor motivation with monotonous sessions, without being authentic, allowing for flexibility of content in various contexts.

- F6. I had quite a few problems with my tutor, she wouldn't let me perform in the classroom, they were ruled by shouting, I wanted to change that, but it wasn't possible. She told me I had to shout because they wouldn't listen to me if I did not. Unfortunately, the classes were mechanical, routine, without methodology, and the students were constantly bored. When she left me alone, I liked to do the sessions in my own way, but she limited me when my tutor was there.

Category 6: Analysis based on comparative strategies and anecdotes that drive the restructuring of my classroom performance.

- M1. I have reflected, comparing how I was taught and how I would like to teach more than anything else I have understood that the routine and the mechanism does not favour to provoke the interest of wanting and learning, in the person I use the anecdotes as a means to reflect and to change some forms that I evidence that they were not correct.

- F1. From the moment my tutor starts with his theoretical learning sessions, they lead me to think about how I was taught long ago. I think that this will not help my professional training, nor does it contribute to the students' learning. So I think I must do the opposite, I will apply planned sessions, with an active methodology... I will have to train myself. 


\section{Participants' Perceptions and beliefs about Satisfaction with the Training Programme}

Pedagogical beliefs are rooted as personal reconstructions (Forgiony-Santos, 2017). Therefore, it is urgent to make fundamental changes in the conception of teaching, showing inconsistency between theory and practice (Solis, 2015), to address diversity from the curriculum (Paz, 2018), where interventions on how to act and be able to respond to diversity are limited.

Category 7: Low level of contribution because they lack didactics that do not allow adequate development of competences.

- M5. In my opinion, the contribution was minimal. Many teachers only focused on teaching theoretical encyclopedias with no teaching strategies. Moreover, due to the new university law requirements, they ask for a bachelor's and a master's degree. Unfortunately, the research subject does not favour this end, since the classes are very theoretical. Those who do not teach and do not favour our professional training are not speciality teachers.

- F6. The elaboration of sessions contributed a lot to carrying them out by myself and being able to dictate them in the classroom as a model to my classmates in the didactic subjects. Still, the reality is different, when you are in front of children, I consider that you should have schools where you can visit to work freely and that provide the facilities to do research work and model practices to test the development of the sessions and to analyse and reconstruct that experience, applying diverse strategies.

Category 8: Rethinking to work the formative evaluation and design of the pedagogical activities contextualised by the diversity of rhythms and learning styles.

- M6. I still have gaps and needs in my training, but what I would recommend for these continuous practices is that they change the system of monitoring pre-professional practices, that the teachers in charge of monitoring are more committed to our evolution of professional and personal growth, taking into account the diversity of learning styles and rhythms, which we are not used to managing, from a learning session that promotes scales to identify those rhythms and learning styles, which are generated.

- F2. With what I have experienced in my practices, I have to improve, innovate, train myself, and read more about pedagogy and methodologies, and now I realise that if you don't know the students realise it and make fun of it. Therefore, the learning sessions have to be located and the formative evaluation that will allow channelling the advances of the students. Because before my evaluation was focused on the summative, and I didn't worry about seeing how they were progressing in their performance.

\section{Category 9: Predominance of Behavioral Methodology}

- M2. Now that I have done my internship in two educational institutions, I realise that nothing has changed since I graduated. Classroom teachers still use the same routine and mechanical forms in their work. I do not find coherence between what we are taught (theories, approaches, methodologies, resources, evaluation) and what is worked on in the classroom.

- F4. In the classroom, there must be moments or activities planned not to overwhelm the students. Not everything must be dictated and copied; without having a vision, they become exhausted and are not in their faculties to continue learning. The proposal must generate play spaces, organise the classroom in a non-linear way, and make visits to different spaces to generate learning and experience situated learning. It would be good to systematise these experiences that are very rich and extraordinary.

\section{Changes in the Conception of the Gender Approach}

There are gender differences, with greater preference for female students, determined by characteristics of greater attachment of male teachers to them, in the opportunities for tasks and assessments with differentiated evaluations based on their physical appearance; promoting an imbalance in the distribution of opportunities among the perceptions of male students, these gender biases have an influence that causes feelings of exclusion and discrimination. Due to this, we must eradicate the obstacles that still impede gender equality through the mainstreaming of the training curriculum.

Category 10: Obvious discrepancies in treatment, a greater sense of female preference because of their fragility and harshness to male students. 
- M3. In general, in the faculty, the treatment of women is very patient, friendly, and there is an attachment from the male teachers. But the opposite happens with the men, and they treat us harshly, they call us by our surnames, while their first names call the female students, they are asked to help them receive their papers, or they talk to them sometimes they receive better grades.

- $\quad$ F3. In my practice I realised that the students in my classroom were more attached to the male teachers that we thought were more understanding, I think this idea was banished when we were taught by more than two female teachers, in the speciality, the treatment was equal, the grades were around what we were evaluated with the established criteria, but there are always male teachers that are preferred and give them higher grades.

\section{Conclusions}

This study examined the effectiveness, impact and transference of pedagogical practices in their trajectory and the trends in the curricular and formative development of the services offered in the Faculty of Educational Sciences. The findings revealed that teacher training constitutes a fundamental element in the improvement of the quality of our educational system, but there is a strong dissociation between theoretical and practical training; as well as the deficient training to work with students with special needs, in this trajectory, there is a set of feelings such as anger, rage, emotion, satisfaction and joy, which can lead to high levels of frustration, but students showed a counter-response of being able to claim as a personal challenge the optimisation of their skills, based on their interest, effort and commitment coinciding with the study of Beraza (2017).

However, the learning experiences acquired in initial training must lead to systematisation of practice to analyse this reality and propose a transformation that contributes to professional and personal growth (Beltrán et al., 2012). In such way, it allows for collegial training and accompaniment as a means to be able to reflect on and propose good educational practices, where the university proposes new teaching models and does not limit itself to being a transmitter.

Finally, it is impossible to develop good practices if there are no universities that take on commitments and considerations to analyse, debate, and internalise students' experiences in training (Villalba-Condori and OlivaCórdova, 2019). It is essential to strengthening the training triad between the student, the university advisor and the classroom tutor to optimise the training process. In this way, the teaching practices of the last four semesters should be rethought, where the living link with schools is managed, the process of insertion of students is supervised, and their performance is evaluated (Ezquerra et al., 2015), where these experiences are systematised and communicated, for decision-making in the curricular training processes (Oliva Córdova, Amado-Salvatierra and Villalba Condori, 2019).

This study opens up the possibilities of knowing the expectations of the formator-tutors and university teachers, for an in-depth study that allows for the evaluation of profiles and formative itineraries and proposing narratives that promote analysis and reflection.

\section{References}

1. Álvarez, C.Á. (2012). The theory-practice relationship in the teaching-learning processes. Educatio Siglo XXI, 30(2), 383-402. https://revistas.um.es/educatio/article/view/160871

2. Arias-Chávez, D., Ramos-Quispe, T., Villalba-Condori, K.O., \& Postigo-Zumarán, J.E. (2020). The characteristics of academic plagiarism in four universities in Arequipa: A comparative study conducted on male and female students. International Journal of Innovation, Creativity and Change, 11(10), 358373.

3. Bedacarratx, VDL Á. (2012). Future teachers and construction of a professional identity: a psychosocial look at the processes that are put into play in the training courses in practice. Electronic journal of educational research, 14(2), 133-149.

4. Beltrán, M., Iparraguirre, A., Castagno, M., Fornasari, M., \& Gutierrez, V. (2012). The process of construction of professional identity in pre-professional practices. Some senses constructed by students of Educational Context Psychology. Research Yearbook of the Faculty of Psychology, (1). https://revistas.psi.unc.edu.ar/index.php/aifp/article/view/2923

5. Beraza, M.A.Z. (2017). The Practicum and external internships in university education. Practicum Magazine, 6(1), 1-23.

6. Calixto, A.R.J., Abascal, I.C., \& Martínez, P.L.V. (2015). Construction and validation of instruments for health managers from a gender perspective. Sanitary Horizon, 14(3), 101-110. https://doi.org/10.19136/hs.v14i3.979 
7. Chavdarova, L., \& Piperkova, E. (2020). Diagnostic information and accuracy improvement using simultaneous multifunctional SPECT/CT imaging. Radiology and Radiology, 59(2), 139-150.

8. Contreras Contreras, C., Monereo Font, C., \& Badia Garganté, A. (2010). Exploring identity: How do university teachers deal with critical incidents that occur in future teacher training classrooms? Pedagogical Studies (Valdivia), 36(2), 63-81. https://doi.org/10.4067/s0718-07052010000200004

9. Deng, L., Zhu, G., Li, G., Xu, Z., Rutter, A., \& Rivera, H. (2018). Student teachers' emotions, dilemmas, and professional identity formation amid the teaching practicums. The Asia-Pacific Education Researcher, 27(6), 441-453. https://doi.org/10.1007/s40299-018-0404-3

10. Díaz Díaz, H. (2015). Teacher training in Peru: Realities and trends. Santillana Foundation.

11. Suresh, P., \& Rajest, S.S. (2019). An analysis of psychological aspects in student-centered learning activities and different methods. Journal of International Pharmaceutical Research, 46(1), 165-172.

12. Lydia, E. L., Kannan, S., SumanRajest, S., \& Satyanarayana, S. (2020). Correlative study and analysis for hidden patterns in text analytics unstructured data using supervised and unsupervised learning techniques. International Journal of Cloud Computing, 9(2-3), 150-162.

13. Ezquerra-Martínez, Á., Juanas-Oliva, Á.D., \& Martín del Pozo, R. (2015). Study on the activities carried out in the university teaching practice for the initial training of primary and secondary teachers. Teachers. Journal of Curriculum and Teacher Training, 19(1), 330-345.

14. Feixas, M., Lagos, P., Fernández, I., \& Sabaté, S. (2015). Models and trends in research on effectiveness, impact and transfer of teacher training in higher education. Educate, 51(1), 81-107.

15. Santos, J.F. (2016). Pedagogical practices: Conceptions, roles and methods in the training of the Bolivarian psychologist 1. Pedagogical practices, 195.

16. Garvanska, G., Totev, M., Genova, K., Shivachev, H., \& Tsilkov, D. (2020). Bronchogenic cyst from the mediastinum extending into the retroperitoneum. Radiology and Radiology, 59(2), 174-177.

17. Gilbert, A. \& Gibbs, G. (1999). A proposal for an international collaborative research programme to identify the impact of initial training on university teachers. Research and Development in Higher Education, 21(2), 131-143.

18. González, N., Eguren, M., \& Belaunde, CD (2017). From the classroom: an approach to the pedagogical practices of the Peruvian teacher. Institute of Peruvian Studies.

19. Gorichon, S., Ruffinelli, A., \& Cisternas León, T. (2015). Relations between Initial Training and Professional Initiation of teachers. Principles and challenges for practical training. Education Notebook, 66, 1-20.

20. Herrera, J. (2017). Qualitative research, 1-29.

21. http://biblioteca.udgvirtual.udg.mx:8080/jspui/bitstream/123456789/1167/1/La\%20investigaci\%C3\%B3 n\%20cualitativa.pdf.

22. Jones, M., Hobbs, L., Kenny, J., Campbell, C., Chittleborough, G., Gilbert, A., \& Redman, C. (2016). Successful university-school partnerships: An interpretive framework to inform partnership practice. Teaching and Teacher Education, 60, 108-120.

23. Kreber, C., Brook, P., \& Policy, E. (2001). Impact evaluation of educational development programmes. International Journal for Academic Development, 6(2), 96-108. https://doi.org/10.1080/13601440110090749

24. Díaz Larenas, C., \& Bastías Díaz, C. (2012). An approach to the communication patterns between the mentor teacher and the teacher-student in the context of pedagogical practice. Education XX1, 15(1), 241-263. https://doi.org/10.5944/educxx1.15.1.158

25. Loughran, J. (2014). Professionally Developing as a Teacher Educator. Journal of Teacher Education, 65(4), 271-283. doi:10.1177/0022487114533386

26. Martín-Gutiérrez, Á., Conde-Jiménez, J., \& Mayor-Ruiz, C. (2014). The professional teaching identity of new university teachers. REDU. Journal of university teaching, 12(4), 141-160.

27. Martínez Domínguez, B., Martínez Domínguez, I., Alonso Sáez, I., \& Geruzaga Amundarain, M. (2013). Service-learning, an opportunity to advance in educational innovation within the University of the Basque Country. Pedagogical Trends, 21, 99-117.

28. Córdova, L.M.O., Amado-Salvatierra, H.R., \& Condori, K.O.V. (2019). An Experience Making Use of Learning Analytics Techniques in Discussion Forums to Improve the Interaction in Learning Ecosystems. In International Conference on Human-Computer Interaction, Springer, Cham, 64-76. https://doi.org/10.1007/978-3-030-21814-0_6

29. Paz Maldonado, E.J. (2018). The training of university teachers for the attention to diversity in higher education. IE Journal of educational research of REDIECH, 9(16), 67-82.

30. Pidello, M.A., Rossi, B., \& Sagaztizabal, M.D.L.Á. (2013). The voices of teachers: reasons for choosing the teaching career, underlying values. Education, 22(43), 113-128. 
31. Pillen, M., Beijaard, D., \& Brok, P (2013). Tensions in beginning teachers' professional identity development, accompanying feelings and coping strategies. European Journal of Teacher Education, 36(3), 240-260.

32. Quattrocchi, P., Flores, C., Cassullo, G., Moulia, LOURDES, De Marco, MARIANA, Shaferstein, CAROLINA, \& Siniuk, D. (2017). Motivation and gender in the choice of career. Journal of Education and Development, 41, 27-35.

33. Quispe-Bendezú, L.E., Araujo-Castillo, R.L., García-Tejada, J.E., García-Tejada, Y., Sprock, A.S., \& Villalba-Condori, K.O. (2020). Relationship between academic procrastination and attributions of achievement motivation. International Journal of Learning, Teaching and Educational Research, 19(1), 188-205.

34. Gupta, R.K. (2018). Employment Security and Occupational Satisfaction in India. Journal of Advanced Research in Dynamical \& Control System, 10(10), 244-249.

35. Gupta, R.K. (2019). Minimum Wage and Minimum Work Hour in India. Journal of Advanced Research in Dynamical \& Control System, 11(02-Special Issue), 2402-2405.

36. Gupta, R.K., \& Singh, D.B. (2020). Minimum Wage and Minimum Work Hour in India," The Journey of Single Taxation System: A Comprehensive study of GST in India. International Journal of Disaster Recovery and Business Continuity, 11(03), 3022 -3030.

37. Rodríguez, R.S., Gracia, E.P., Chan, M.B., \& Camargo, A.C. (2019). Respect and gender equality in initial teacher training. Research Cadernos, 49(174), 152-166.

38. Suman Rajest, S., \& Suresh, D.P. (2018). 21st Century Learners' Student-Centered Learning Various Stages. In International Conference, Age and Content in Journey of Language by VISTAS (Tamil Department), 1(1), 474-492.

39. Suman Rajest, S., \& Suresh, D.P. (2018). Impact of 21 st century's different heads of learning skills for students and teachers. International Journal of Multidisciplinary Research and Development, 5(4), 170178.

40. Salazar-gomez, E., \& Tobon, S. (2018). Documentary analysis of the teacher training process in accordance with the knowledge society. Espacios Magazine, 39(53).

41. Sánchez Ponce, C. (2013). Structures of initial teacher training: Proposal of a classification system for its analysis. Educational Profiles, 35 (142), 128-148.

42. Serrano, J.A. (2016). Basic education: experience in the trade in being a student, 149-164. En Perin Vicentini, P.; Da Cunha, J.L.; Maciel Cardoso, L.A. (Orgs.) Training and practical experiences from initiation to docência. Curitiba: Editora CRV.

43. Solis, CA (2015). Beliefs about teaching and learning in university teachers: Review of some studies. Purposes and Representations, 3(2), 227-260.

44. Stes, A., Min-Leviveld, M., Gijbels, D. \& Van Petegem, P. (2010). The Impact of Instructional Development in Higher Education: The State-of-the-art of the Research. Educational Research Review, 5(1), 25-49.

45. Relinque, C.S., del Moral Arroyo, G., \& Fernández, M.T.G. (2013). Practical tips for writing a qualitative publishable article in Psychology. Psychosocial Intervention, 22(1), 71-79.

46. Suman Rajest, S., \& P. Suresh. (208). "The "Four Cs" Education for 21st Century's Learners". Research Guru Online Journal of Multidisciplinary Subjects (RGOJMS), 7(1), 888-900.

47. Tobón, S., MARTINEZ, JE, Valdéz, E., \& Quiriz, T. (2018). Pedagogical practices: Analysis through conceptual cartography. Espacios Magazine, 39(53), 31 - 46.

48. Jiménez, IV (2012). The gender perspective from the supervised practice students of the Counseling career at the National University (UNA) / Perspective of gender with students of practice in the career of Counseling UNA. Research News in Education, 12 (2). https://doi.org/10.15517/aie.v12i2.10275

49. Villalba-Condori K.O., Adúriz-Bravo A., Lavonen J., Wong LH., Wang TH. (2020). Importance of the Concept of "Competency" in Science Teacher Education: What Are the Professional Competencies for Science Teachers? In: Villalba-Condori K., Aduríz-Bravo A., Lavonen J., Wong LH., Wang TH. (eds) Education and Technology in Sciences. CISETC 2019. Communications in Computer and Information Science, 1191. https://doi.org/10.1007/978-3-030-45344-2_1

50. Villalba-Condori, K.O., \& Oliva-Córdova, L.M. (2019). Teacher training to develop computational thinking at the primary education level. Journal of Advanced Research in Dynamical and Control Systems, 11(10), 91-98. https://doi.org/10.5373/JARDCS/V11I10/20193010

51. Villalba-Condori, K.O., Adúriz-Bravo, A., García-Peñalvo, F.J., \& Lavonen, J. (2019). What is new in teaching science structured around the notion of 'scientific competence'? Paper presented at the CEUR Workshop Proceedings, 2555, 12-15. http://ceur-ws.org/Vol-2555/paper0.pdf

52. Yovchev, D., Yordanova, G., Mihaylova, H., Miteva-Yovcheva, N. (2020). CBct finding of peripheral ossiyfying fibroma of the mandible. Radiology and Radiology, 59(1), 75-78. 
53. Zambrano, E.L. (2018). Pedagogical practices for the development of civic skills. Electronic journal of educational research, 20(1), 69-82.

54. Zeichner, K. (2010). New epistemologies in teacher training. Rethinking the connections between campus subjects and internship experiences in teacher training at university. Interuniversity journal of teacher training, 24 (2), 123-149. 